\title{
Perlindungan Hukum Pemegang Saham Minoritas Perseroan Terbatas Tertutup dan Keadilan Berdasar Pancasila
}

\author{
Mustaqim Mustaqim ${ }^{1 *}$, Agus Satory ${ }^{2}$ \\ ${ }^{1,2}$ Fakultas Hukum Universitas Pakuan, Bogor, Indonesia \\ *E-mail: mustaqimsh8@gmail.com
}

\begin{abstract}
Legal protection for the majority shareholders is sufficiently guaranteed, especially through the mechanism of the RUPS, but this is not the case for minority shareholders, thus creating an injustice problem for minority shareholders. The purpose of this study is to uncover and find out legal protection for minority shareholders in a limited liability company based on Pancasila justice. This research is normative juridical so it uses secondary data with the law approach and qualitative data analysis. The results showed that the General Meeting of Shareholders did not reflect legal protection for minority shareholders, because in every decision making through the General Meeting of Shareholders and various other decisions based on the attendance quorum about the majority of votes present at the General Meeting of Shareholders. Such matter is detrimental to the interests of minority shareholders because without the presence of minority shareholders, a General Meeting of Shareholders can be held, while minority shareholders also have the same rights and obligations and responsibilities. The majority of shareholders hold a large and full control over the company, resulting in minority shareholders, there is no guarantee to get justice based on Pancasila justice. Therefore, the General Meeting of Shareholders must be held if attended by all shareholders with voting rights present or represented. If this is not the case, the results of the General Meeting of Shareholders may be canceled.
\end{abstract}

Keywords: Legal Protection; Minority Shares; Justice

\section{A. PENDAHULUAN}

Pancasila merupakan cita hukum karena kedudukannya sebagai pokok kaedah fundamental negara (staatfundamental norm) yang mempunyai kekuatan sebagai grundnorm sehingga semua produk hukum ditujukan untuk mencapai ide-ide yang didukung Pancasila. ${ }^{1}$ Sebagai keyakinan normatif, Pancasila berfungsi sebagai norma dasar yang memberi fondasi moral etik dan memiliki misi utama yaitu mewujudkan Indonesia menjadi "rumah bagi semua penghuninya yang majemuk untuk hidup tentram didalamnya". Hal tersebut mengharuskan adanya perlindungan yang sama bagi semua unsur nation dari sabang sampai merauke tanpa kecuali, adanya hak yang sama bagi seluruh suku bangsa yang ada untuk mendiami rumah Indonesia, dan adanya kewajiban

1 Notonagoro. (1974). Pancasila Dasar Falsafah Negara, Jakarta: Pancuran Tujuh, h. 
yang sama bagi para penghuninya untuk menjaga kelestarian rumah Indonesia itu dan menjaga ketentraman hidup bersama. ${ }^{2}$

Dalam Negara Hukum Pancasila, yang menitikberatkan pada asas kesamaan dalam hukum dan perlindungan hukum sesuai dengan bunyi Pasal 27 ayat (1) Undang-undang Dasar 1945 yang berbunyi:Segala warga negara bersamaan kedudukannya di dalam hukum dan pemerintahan dan wajib menjunjung hukum dan pemerintahan itu dengan tidak ada kecualinya.Keadilan yang dimaksud dalam konsep Negara hukum Indonesia adalah bukan hanya keadilan hukum (legal justice), tetapi juga keadilan sosial (sociale justice).

Menurut teori keadilan antara lain dikemukakan, filosofi utama dari hakekat hukum adalah keadilan, tanpa keadilan hukum tidak layak disebut hukum. Keadilan merupakan suatu hasil pengambilan keputusan yang mengandung kebenaran, tidak memihak, dapat dipertanggungjawabkan dan memperlakukan setiap orang pada kedudukan yang sama dalam hukum.

Perkembangan dunia usaha di Indonesia terlihat semakin meningkat terutama usaha-usaha di sektor swasta. Peran para pengusaha swasta di Indonesia kebanyakan memilih usahanya dengan mendirikan suatu badan usaha yang berbadan hukum yaitu berupa Perseroan Terbatas.Menurut konsep dalam perseroan terbatas, PT adalah asosiasi modal yang berstatus badan hukum yang mandiri terlepas dari orang perorangannya. (Pasal 1 (1) Undang-undang No. 40 Tahun 2007 tentang Perseroan Terbatas).

Rapat Umum Pemegang Saham (RUPS) merupakan organ dalam perseroan terbatas dan mempunyai wewenang yang tidak diberikan kepada direksi dan dewan komisaris. Rapat Umum Pemegang Saham mempunyai hak untuk memperoleh segala macam keterangan yang diperlukan yang berkaitan dengan jalannya Perseroan Terbatas, Namun demikian dalam kewenangan RUPS juga terdapat batas, yaitu kewenangan yang dijalankan tidak diberikan kepada direksi atau dewan komisaris dan tidak keluar dari Undang-undang Nomor 40 tahun 2007 atau anggaran dasar.

Rapat Umum Pemegang Saham merupakan perwujudan kepentingan bagi para pemegang saham, hal terebut karena pemegang saham dapat memberikan berbagai masukan yang berkaitan dengan perkembangan perseroan agar perseroan berkembang menjadi lebih baik sesuai dengan tujuan didirikan perusahaan. Namun demikian, kadangkadang RUPS sulit dilaksanakan, hal ini terjadi karena adanya berbagai kepentingan para pemegang saham dalam RUPS, sehingga kuorum untuk dapat dilangsungkan RUPS sangat sulit, karena kuorum tidak terpenuhi.

Pasal 86 ayat 1 Undang-Undang Nomor 40 Tahun 2007 berbunyi:

"RUPS dapat dilangsungkan jika dalam RUPS lebih dari $1 / 2$ (satu perdua) bagian dari jumlah seluruh saham dengan hak suara hadir atau diwakili, kecuali Undangundang dan/atau anggaran dasar menentukan jumlah kuorum yang lebih besar".

Berdasarkan bunyi Pasal 86 ayat (1) tersebut tampak bahwa, apabila kuorum belum mencapai lebih dari 50\% dari jumlah saham sebagai hak suara yang hadir, makaRUPS tidak dapat dilangsungkan. Namun demikian, oleh karena biasanya dalam perseroan terbatas terdapat dua kelompok pemegang saham yaitu pemegang saham mayoritas dan pemegang saham minoritas, maka seringkali pemegang saham mayoritas sudah merasa bahwa jumlah sahamnya sudah mencukupi kuorum untuk dilangsungkannya RUPS, maka

2 Tanya, Bernard L. dkk. 2015, Teori Hukum, Strategi Tertib Manusia Lintas Ruang dan Generasi, Yogyakarta: Genta Publishing, h. 
RUPS tetap dilangsungkan dengan mengabaikan kepentingan pemegang saham minoritas yang tidak hadir dalam RUPS. Maksudnya jika pemegang saham mayoritas sudah hadir dan hak suaranya sudah mencukupi untuk dilangsungkannya RUPS, maka RUPS tetap dilangsungkan oleh pemegang saham mayoritas dan mengabaikan hak suara yang hadir dari pemegang saham minoritas, meskipun pemegang saham mempunyai hak yang sama dalam RUPS, dalam Undang-undang Nomor 40 tahun 2007 juga sudah diatur mengenai tanggung jawab dari masing-masing organ perseroan dan juga pemegang saham. Namun, dalam prakteknya sering timbul perselisihan antara organ perseroan dengan pemegang saham, atau bisa terjadi diantara pemegang saham itu sendiri.

Perbedaan antara pemegang saham mayoritas dengan pemegang saham minoritas adalah dalam hal kepemilikan jumlah saham, sehingga sering berlaku prinsip, pemegang saham mayoritas yang menyebabkan pemegang saham minoritas berada pada posisi yang lemah dalam menegakkan kepentingan dan haknya yang tidak mampu menghadapi tindakan Direksi atau Komisaris yang merugikan dirinya dan kepentingannya dalam perseroan. Hal ini disebabkan karena pemegang saham mayoritas identik dengan Direksi atau Komisaris selaku organ dalam perseroan.Pemegang saham sebagai pemilik modal dalam Perseroan Terbatas dalam kenyataannya akan membentuk dua komunitas pemegang saham yaitu pemegang saham mayoritas dan pemegang saham minoritas.

Perlindungan hukum bagi pemegang saham mayoritas pada dasarnya cukup terjamin, terutama melalui mekanisme RUPS, yang apabila keputusan RUPS tidak dapat diambil secara musyawarah, maka akan diambil dengan keputusanRUPS yang diterima oleh mayoritas pemegang saham. Kondisi semacam inilah yang menjadi awal permasalahan dalam perseroan terbatas kaitannya dengan pemegang saham. Jikalau setiap keputusan diambil sesuai dengan suara terbanyak yaitu oleh pemegang saham mayoritas saja dan hak suara dari pemegang saham minoritas tetap diabaikan, maka hal ini akan menimbulkan ketidak adilan_dan kerugian bagi pemegang saham yang minoritas. Padahal pemegang saham minoritas juga mempunyai hak dan harus mendapatkan perlindungan pula.

Konsep dan pengaturan hukum tentang prinsip perlindungan hukum bagi pemegang saham minoritas merupakan hal yang mungkin masih dianggap baru dan kurang mendapatkan perhatian dalam peraturan perundang-undangan hukum korporasi di Indonesia selama ini. Hal tersebut perlu mendapatkan perhatian untuk perbaikan atas peraturan yang berkaitan dengan hukum korporasi khususnya yang berkaitan dengan pemegang saham minoritas. Hal tersebut karena disinyalir hampir selalu dirugikan kedudukannya dalam perseroan. Pemegang saham minoritas tidak jarang hanya dijadikan sebagai pelengkap dalam sebuah perusahaan. Dalam RUPS sebagai mekanisme pengambilan keputusan di perusahaan pemegang saham minoritas ini selalu kalah dibanding pemegang saham mayoritas, sebab pola pengambilan keputusan lebih banyak di dasarkan pada besarnya prosentase saham yang dimiliki. Keadaan yang demikian ini akan semakin parah jika ternyata pemegang saham mayoritas menggunakan peluang ini untuk mengendalikan perusahaan berdasarkan kepentingannya saja dan tidak mengindahkan kepentingan pemegang saham minoritas. Pemegang saham mayoritas mengendalikan perusahaan menurut kemauannya sendiri dan mengabaikan kemauan dari pemegang saham minoritas.

\section{B. METODE PENELITIAN}

Penelitian ini bersifat yuridis normatif oleh karena itu menggunakan data sekunder berupa bahan hukum primer, bahan hukum sekunder dan bahan hukum tersier, dalam 
melakukan penelitian ini menggunakan pendekatan undang-undang (statute approach) yaitu pendekatan penelitian yang mengutamakan bahan hukum yang berupa peraturan perundang-undangan sebagai bahan acuan dasar. Bahan hukum yang diperoleh selanjutnya dilakukan pembahasan, pemeriksaan dan pengelompokan ke dalam bagianbagian tertentu untuk diolah menjadi data informasi. Hasil analisis bahan hukum kemudian diinterpretasikan. Kegiatan yang dilakukan dalam analisis data adalah dengan cara data yang diperoleh di analisis secara deskriptif kualitatif

\section{PEMBAHASAN}

\section{Perlindungan hukum bagi pemegang saham minoritas pada perseroan terbatas tertutup}

Perlindungan hukum merupakan salah satu unsur terpenting dari suatu negara hukum, karena dalam pembentukan suatu negara hukum menyangkut pula berbagai peraturan hukum yang mengatur warga negaranya. Hal tersebut mengingat dalam suatu negara senantiasa terjadi suatu hubungan hukum antara berbagai pihak anggota masyarakat, baik warga negara maupun warga negara asing. Dari berbagai hubungan hukum yang terjadi akan melahirkan hak dan kewajiban antara pihak dan dalam hal demikian diperlukan adanya suatu perlindungan hukum bagi setiap orang. Perlindungan hukum merupakan kewajiban Negara, oleh karena itu negara wajib memberi perlindungan hukum kepada setiap orang jika dirugikan oleh pihak lain.

Menurut teori keadilan antara lain filosofi utama dari hakekat hukum adalah keadilan, tanpa keadilan hukum tidak layak disebut hukum. Keadilan merupakan suatu hasil pengambilan keputusan yang mengandung kebenaran, tidak memihak, dapat dipertanggungjawabkan dan memperlakukan setiap orang pada kedudukan yang sama dalam hukum. Demikian pula dalam Negara Hukum Pancasila, menitikberatkan pada asas kesamaan dalam hukum dan perlindungan hukum sesuai dengan bunyi Pasal 27 ayat (1) Undang-undang Dasar 1945 yang, bahwa: "Segala warga negara bersamaan kedudukannya di dalam hukum dan pemerintahan dan wajib menjunjung hukum dan pemerintahan itu dengan tidak ada kecualinya". Keadilan yang dimaksud dalam konsep Negara hukum Indonesia adalah bukan hanya keadilan hukum (legal justice), tetapi juga keadilan sosial (sociale justice)

Di Indonesia perlindungan hukum oleh negara dasar atau landasannya adalah Pancasila sebagai ideologi dan falsafah negara. Prinsip perlindungan hukum di Indonesia adalah prinsip pengakuan dan perlindungan terhadap harkat dan martabat manusia yang bersumber pada Pancasila.Perlindungan hukum pada dasarnya merupakan upaya melindungi kepentingan seseorang dengan cara mengalokasikan suatu kekuasaan kepadanya untuk bertindak dalam kepentinganya tersebut. Selanjutnya, salah satu sifat dan sekaligus merupakan tujuan dari hukum adalah memberikan perlindungan (pengayoman) kepada masyarakat. Oleh karena itu, menurut Satjipto Rahardjo ${ }^{3}$, perlindungan hukum terhadap masyarakat tersebut harus diwujudkan dalam bentuk adanya kepastian hukum. Perlindungan hukum dengan demikian, merupakan gambaran dari bekerjanya fungsi hukum untuk mewujudkan tujuan-tujuan hukum, yakni keadilan, kemanfaatan dan kepastian hukum.

Rapat Umum Pemegang Saham (RUPS) merupakan rapat dari para pemilik kekuasaan tertinggi dalam perusahaan yaitu pemegang saham. makapemegang saham

\footnotetext{
3 Rahardjo, Satjipto. (1983). Permasalahan Hukum di Indonesia, Bandung: Alumni, h.
} 
melalui RUPS memiliki hak tertinggi untuk pengambilan keputusan penting terutama yang berkaitan dengan modal yang disetor. Sedangkan hal-hal yang terkait dengan operasional perusahaan diserahkan kepada manajemen eksekutif yaitu dewan komisaris dan direksi. Para eksekutif diberi tanggung jawab untuk mengambil keputusan berkaitan dengan perusahaan yang menunjang tercapainya kepentingan pemegang saham.

Pemegang saham sebagai principal dan eksekutif sebagai agent sesuai dengan teori keagenan. Manajemen eksekutif terdiri atas dewan komisaris dan direksi. Dewan komisaris bertugas melakukan pengawasan pemutusan dan pelaksanaan kebijakan serta memberikan nasehat kepada direksi. Peran pengawasan oleh dewan komisaris merupakan tugas yang penting untuk mendukung terlaksananya good corporate governance (GCG). Di sisi lain, direksi memiliki tanggung jawab yang lebih besar lagi yaitu berwenang dan bertanggung jawab penuh atas kepengurusan perusahaan dan melakukan tindakan yang mendukung kepentingan perusahaan. Meski memiliki tugas yang berbeda, namun keduanya memiliki kewajiban yang sama untuk bersinergi mengarahkan perusahaan menuju pencapaian tujuan perusahaan. Salah satu upaya yang dilakukan oleh mereka yaitu mengdakan RUPS untuk mewujudkan GCG tersebut. Rapat Umum Pemegang Saham (RUPS) menurut Pasal 1 angka 4 Undang-Undang Nomor 40 Tahun 2007 tentang Perseroan Terbatas adalah Organ Perseroan yang mempunyai wewenang yang tidak diberikan kepada Direksi atau Dewan Komisaris dalam batas yang ditentukan dalam Undang-Undang ini dan/atau anggaran dasar.

Pemegang saham berhak memperoleh keterangan yang berkaitan dengan Perseroan dari Direksi dan/atau Dewan Komisaris, sepanjang berhubungan dengan mata acara rapat dalam RUPS dan tidak bertentangan dengan kepentingan Perseroan. Mata acara rapat lain-lain tidak berhak disetujui oleh RUPS, kecuali semua pemegang saham yang hadir atau wakilnya menyetujui adanya penambahan mata acara rapat.Penyelenggaraan RUPS dapat dilakukan atas permintaan 1 (satu) orang atau lebih pemegang saham yang bersamasama mewakili 1/10 (satu persepuluh) atau lebih dari jumlah seluruh saham dengan hak suara kepada Direksi dengan Surat Tercatat disertai alasannya dan tembusannya disampaikan kepada Dewan Komisaris. Direksi wajib melakukan pemanggilan RUPS dalam jangka waktu paling lambat 15 (lima belas) hari terhitung sejak tanggal permintaan penyelenggaraan RUPS diterima. Dalam hal Direksi tidak melakukan pemanggilan RUPS, maka pemegang saham mengajukan kembali permintaan penyelenggaraan RUPS kepada Dewan Komisaris. Dewan Komisaris wajib melakukan pemanggilan RUPS dalam jangka waktu paling lambat 15 (lima belas) hari terhitung sejak tanggal permintaan penyelenggaraan RUPS diterima. Jika dalam hal Direksi atau Dewan Komisaris ternyata tidak melakukan pemanggilan penyelenggaraan RUPS, maka pemegang saham dapat mengajukan permohonan kepada ketua pengadilan negeri yang daerah hukumnya meliputi tempat kedudukan Perseroan untuk menetapkan pemberian izin kepada pemohon (pemegang saham) melakukan sendiri pemanggilan RUPS tersebut.

Pemanggilan RUPS dilakukan dalam jangka waktu paling lambat 14 (empat belas) hari sebelum tanggal RUPS diadakan, dengan tidak memperhitungkan tanggal pemanggilan dan tanggal RUPS. Pemanggilan RUPS dilakukan dengan surat tercatat dan/atau dengan iklan dalam surat kabar. Dalam panggilan RUPS dicantumkan tanggal, waktu, tempat, dan mata acara rapat disertai pemberitahuan bahwa bahan yang akan dibicarakan dalam RUPS tersedia di kantor Perseroan sejak tanggal dilakukan pemanggilan RUPS sampai dengan tanggal penyelenggaraan RUPS.

RUPS yang diselenggarakan Direksi berdasarkan panggilan RUPS dapat membicarakan masalah yang berkaitan dengan alasan permintaan oleh pemegang saham dan atau Dewan Komisaris dan mata acara rapat lainnya yang dipandang perlu oleh 
Direksi sesuai dengan panggilan RUPS. RUPS yang diselenggarakan Dewan Komisaris hanya membicarakan masalah yang berkaitan dengan alasan dimintanya RUPS. Selanjutnya RUPS yang diselengarakan berdasarkan penetapan ketua pengadilan negeri hanya boleh membicarakan mata acara rapat sebagaimana ditetapkan ketua pengadilan negeri. Jika dalam RUPS hadir dan/atau diwakili semua pemegang saham dan semua pemegang saham menyetujui diadakannya RUPS dengan agenda tertentu, RUPS dapat diadakan di manapun dengan memperhatikan bahwa tempat atau lokasi penyelenggaraannya harus masih berada dalam wilayah negara Republik Indonesia. RUPS ini dapat mengambil keputusan jika keputusan tersebut disetujui dengan suara bulat.

Pemegang saham, baik sendiri maupun diwakili berdasarkan surat kuasa berhak menghadiri RUPS dan menggunakan hak suaranya sesuai dengan jumlah saham yang dimilikinya, kecuali bagi pemegang saham dari saham tanpa hak suara. Dalam pemungutan suara, suara yang dikeluarkan oleh pemegang saham berlaku untuk seluruh saham yang dimilikinya dan pemegang saham tidak berhak memberikan kuasa kepada lebih dari seorang kuasa untuk sebagian dari jumlah saham yang dimilikinya dengan suara yang berbeda. Dalam pemungutan suara, anggota Direksi, anggota Dewan Komisaris, dan karyawan perseroan yang bersangkutan dilarang bertindak sebagai kuasa dari pemegang saham. Dalam hal pemegang saham hadir sendiri dalam RUPS, surat kuasa yang telah diberikan tidak berlaku untuk rapat tersebut. Ketua rapat berhak untuk menentukan siapa yang berhak hadir dalam RUPS dengan memperhatikan ketentuan UUPT dan Anggaran Dasar perseroan.

RUPS untuk mengubah Anggaran Dasar dapat dilangsungkan jika dalam rapat paling sedikit $2 / 3$ (dua pertiga) bagian dari jumlah seluruh saham dengan hak suara hadir atau diwakili dalam RUPS dan keputusan adalah sah jika disetujui paling sedikit 2/3 (dua pertiga) bagian dari jumlah suara yang dikeluarkan, kecuali Anggaran Dasar menentukan kuorum kehadiran dan/atau ketentuan tentang pengambilan keputusan RUPS yang lebih besar. Dalam hal kuorum kehadiran tersebut tidak tercapai, dapat diselenggarakan RUPS kedua. RUPS kedua hanya sah dan berhak mengambil keputusan jika dalam rapat paling sedikit 3/5 (tiga perlima) bagian dari jumlah seluruh saham dengan hak suara hadir atau diwakili dalam RUPS dan keputusan adalah sah jika disetujui paling sedikit 2/3 (dua pertiga) bagian dari jumlah suara yang dikeluarkan, kecuali Anggaran Dasar menentukan kuorum kehadiran dan/atau ketentuan tentang pengambilan keputusan RUPS yang lebih besar. Dalam hal kuorum RUPS kedua tidak tercapai, perseroan dapat memohon kepada ketua pengadilan negeri yang daerah hukumnya meliputi tempat kedudukan perseroan atas permohonan perseroan agar ditetapkan kuorum untuk RUPS ketiga. Pemanggilan RUPS ketiga harus menyebutkan bahwa RUPS kedua telah dilangsungkan dan tidak mencapai kuorum dan RUPS ketiga akan dilangsungkan dengan kuorum yang telah ditetapkan oleh ketua pengadilan negeri. Penetapan ketua pengadilan negeri mengenai kuorum RUPS bersifat final dan mempunyai kekuatan hukum tetap. Pemanggilan RUPS kedua dan ketiga dilakukan dalam jangka waktu paling lambat 7 (tujuh) hari sebelum RUPS kedua atau ketiga dilangsungkan. RUPS kedua dan ketiga dilangsungkan dalam jangka waktu paling cepat 10 (sepuluh) hari dan paling lambat 21 (dua puluh satu) hari setelah RUPS yang mendahuluinya dilangsungkan. RUPS untuk menyetujui hal-hal tersebut dapat dilangsungkan jika dalam rapat paling sedikit hadir 3/4 (tiga perempat) bagian dari jumlah seluruh saham dengan hak suara hadir atau diwakili dalam RUPS dan keputusan adalah sah jika disetujui paling sedikit $3 / 4$ (tiga perempat) bagian dari jumlah suara yang dikeluarkan, kecuali Anggaran Dasar menentukan kuorum kehadiran dan/atau ketentuan tentang persyaratan pengambilan keputusan RUPS yang lebih besar. Dalam hal 
kuorum kehadiran tersebut tidak tercapai, dapat diadakan RUPS kedua.

RUPS kedua hanya sah dan berhak mengambil keputusan jika dalam rapat paling sedikit $2 / 3$ (dua pertiga) bagian dari jumlah seluruh saham dengan suara hadir atau diwakili dalam RUPS dan keputusan adalah sah jika disetujui oleh paling sedikit $3 / 4$ (tiga perempat) bagian dari jumlah suara yang dikeluarkan, kecuali Anggaran Dasar menentukan kuorum kehadiran dan/atau ketentuan tentang persyaratan pengambilan keputusan RUPS yang lebih besar.

Dalam hal kuorum RUPS kedua tidak tercapai, perseroan dapat memohon kepada ketua pengadilan negeri yang daerah hukumnya meliputi tempat kedudukan perseroan atas permohonan perseroan agar ditetapkan kuorum untuk RUPS ketiga. Pemanggilan RUPS ketiga harus menyebutkan bahwa RUPS kedua telah dilangsungkan dan tidak mencapai kuorum dan RUPS ketiga akan dilangsungkan dengan kuorum yang telah ditetapkan oleh ketua pengadilan negeri. Penetapan ketua pengadilan negeri mengenai kuorum RUPS bersifat final dan mempunyai kekuatan hukum tetap.

Pemanggilan RUPS kedua dan ketiga dilakukan dalam jangka waktu paling lambat 7 (tujuh) hari sebelum RUPS kedua atau ketiga dilangsungkan. RUPS kedua dan ketiga dilangsungkan dalam jangka waktu paling cepat 10 (sepuluh) hari dan paling lambat 21 (dua puluh satu) hari setelah RUPS yang mendahuluinya dilangsungkan.

Rapat Umum Pemegang Saham Luar Biasa lainnya dapat dilangsungkan jika dalam RUPS lebih dari $1 / 2$ (satu perdua) bagian dari jumlah seluruh saham dengan hak suara hadir atau diwakili, kecuali UUPT ini dan/atau Anggaran Dasar menentukan jumlah kuorum yang lebih besar. Dalam hal kuorum kehadiran tersebut tidak tercapai, dapat diadakan pemanggilan RUPS kedua, dalam pemanggilan RUPS kedua harus disebutkan bahwa RUPS pertama telah dilangsungkan dan tidak mencapai kuorum. RUPS kedua sah dan berhak mengambil keputusan jika dalam RUPS paling sedikit 1/3 (satu pertiga) bagian dari jumlah seluruh saham dengan hak suara hadir atau diwakili, kecuali Anggaran Dasar menentukan jumlah kuorum yang lebih besar, dalam hal kuorum RUPS kedua tidak tercapai, perseroan dapat memohon kepada ketua pengadilan negeri yang daerah hukumnya meliputi tempat kedudukan perseroan atas permohonan perseroan agar ditetapkan kuorum untuk RUPS ketiga. Pemanggilan RUPS ketiga harus menyebutkan bahwa RUPS kedua telah dilangsungkan dan tidak mencapai kuorum dan RUPS ketiga akan dilangsungkan dengan kuorum yang telah ditetapkan oleh ketua pengadilan negeri. Penetapan ketua pengadilan negeri mengenai kuorum RUPS bersifat final dan mempunyai kekuatan hukum tetap. Pemanggilan RUPS kedua dan ketiga dilakukan dalam jangka waktu paling lambat 7 (tujuh) hari sebelum RUPS kedua atau ketiga dilangsungkan. RUPS kedua dan ketiga dilangsungkan dalam jangka waktu paling cepat 10 (sepuluh) hari dan paling lambat 21 (dua puluh satu) hari setelah RUPS yang mendahuluinya dilangsungkan.

Dari berbagai hal yang telah dikemukakan tampak, pemegang saham minoritas beada pada pihak yang lemah dalam hal hak dan kepentingannya dalam Rapat Umum Pemegang Saham. Sedangkan pemegang saham minoritas juga mempunyai hak dan kepentingan yang sama dengan pemegang saham mayoritas. Dengan demikian, pemegang saham minoritas maupun pemegang saham mayoritas mempunyai kedudukan yang sama. Perlindungan hukum bagi pemegang saham adalah kekuatan hukum untuk melindungi pemegang saham dari perbuatan melanggar hukum yang dilakukan oleh organ PT, pemegang saham lainnya maupun pihak lain yang berperan dalam PT, dalam prakteknya sering terjadi perselisihan antara pemegang saham mayoritas dan pemegang saham minoritas, yang akhirnya merugikan kepentingan pemegang saham minoritas. 
Dalam rangka perlindungan hukum bagi pemegang saham minoritas, perlu diberikan hakhak tertentu oleh UUPT agar pemegang saham mayoritas yang memiliki posisi dominan tidak menyalahgunakan kekuasaannya untuk menekan pemegang saham minoritas.

Rapat Umum Pemegang Saham dalam perseroan terbatas tertutup belum mencerminkan adanya perlindungan hukum bagi pemegang saham minoritas. Hal tersebut karena dalam setiap pengambilan keputusan baik keputusan melalui RUPS atau berbagai kebijakan dalam perseroan selalu berdasarkan atas kuorum kehadiran dengan mengacu pada suara terbanyak yang hadir dalam RUPS, hal demikian dapat merugikan kepentingan bagi pemegang saham minoritas, karena tanpa kehadiran pemegang saham minoritas RUPS tetap dapat dilangsungkan sedangkan pemegang saham minoritas mempunyai hak dan kewajiban serta tanggung jawab yang sama terhadap kelangsungan hidup Perusahaan.

Kepentingan pemegang saham harus diwujudkan dalam suatu wadah yang disebut dengan Rapat Umum Pemegang Saham (General Meeting of shareholders). Namun demikian, dalam suatu perseroan sering terdapat hak yang berbeda bagi pemegang saham dalam kualifikasi tertentu, karena dalam perseroan dikenal adanya kelas-kelas saham yang tentu saja memberikan hak yang berbeda antara yang satu dengan yang lain yang dapat dilihat dalam anggaran dasar perseroan yang bersangkutan. Dalam suatu perseroan terbatas biasanya ada dua kualifikasi pemegang saham, yaitu pemegang saham mayoritas dan pemegang saham minoritas. Kedua pemegang saham ini memiliki hak yang sama kedudukannya dalam perseroan, utamanya hak dalam RUPS, namun demikan, antara pemegang saham mayoritas dan pemegang saham minoritas sering terjadi perbedaan perlakuan dalam RUPS tersebut. Perbedaan perlakuan dalam RUPS tersebut terjadi karena pemegang saham mayoritas sering mengabaikan pemegang saham minoritas karena pemegang saham mayoritas merasa lebih memiliki perusahaan.

Prinsip one share, one vote dan mayority rule sebenarnya didasarkanpada suatu pemikiran, pemegang saham mayoritas sebagai penyandang dana utama, selalu dihadapkan pada dua sisi yang kontradiktif. Disatu sisi berharap mendapatkan deviden yang besar, disisi lain dapat menanggung resiko kerugian yang besar juga sesuai dengan jumlah saham yang dimilikinya, sehingga terdapat kecenderungan, pemegang saham mayoritas ingin memonopoli kekuasaan dalam perseroan terbatas. Persoalan ini akan terus menjadi masalah yang tidak kunjung berakhir, jika permasalahannya tidak diselesaikan secara tuntas, karena mekanisme kerja perseroan terbatas yang ada sekarang telah menerima prinsip one share, one vote tersebut. ${ }^{4}$

Berbagai kesewenang-wenangan yang dilakukan oleh pemegang saham mayoritas dapat terjdi terhadap pemegang saham minoritas melalui RUPS. Kesewenang-wenangan itu dapat terjadi oleh karena berlakunya ketentuan one share one vote dan majority rule. Di samping itu, sering pula kepentingan pemegang saham minoritas diabaikan oleh pengurus perseroan, terutama direksi, yang lebih berorientasi kepada kepentingan pemegang saham mayoritas, karena kedudukan pemegang saham mayoritas sangat menentukan nasib posisi hukum anggota pengurus perseroan yang dimaksud. Sistem "one share one vote dan majority rule" telah membuat kedudukan pemegang saham mayoritas menjadi sangat dominan. ${ }^{5}$

4 Wilamarta, Misahardi.. (2005).Hak Pemegang Saham Minoritas Dalam Rangka Good Corporate Governance, Jakarta: Program Pasca Sarjana Fakultas Hukum Universitas Indonesia, h.

5 Sjahdeini, Sutan. Remy. (2005). Pengantar dalam buku Misahardi Wilamarta, Hak Pemegang Saham Minoritas Dalam Rangka Good Corporate Governance, Jakarta: Program Pasca Sarjana Fakultas Hukum Universitas Indonesia, h. 
Sistem One Share One Vote dan Majority Rule, telah membuat kedudukan Pemegang Saham Mayoritas menjadi sangat dominan, karena perseroan didirikan oleh para pemegang saham bertujuan untuk kepentingan semua pemegang saham yang mendirikan, bukan hanya kepentingan sebagian saham saja, sehingga hukum melalui tangan pembuat undang-undang harus mengupayakan agar sistem One Share One Vote dalam implementasinya tidak sampai memungkinkan terjadinya dominasi Pemegang Saham Mayoritas terhadap Pemegang Saham Minoritas.

Merumuskan prinsi-prinsip perlindungan hukum di Indonesia, landasannya adalah Pancasila sebagai ideologi dan falsafah negara. Konsepsi perlindungan hukum bagi rakyat di Barat bersumber pada konsep-konsep Rechtstaat dan "Rule of The Law". Dengan menggunakan konsepsi Barat sebagai kerangka berfikir dengan landasan pada Pancasila, prinsip perlindungan hukum di Indonesia adalah prinsip pengakuan dan perlindungan terhadap harkat dan martabat manusia yang bersumber pada Pancasila. Prinsip perlindungan hukum terhadap tindak pemerintah bertumpu dan bersumber dari konsep tentang pengakuan dan perlindungan terhadap hak-hak asasi manusia karena menurut sejarahnya di Barat, lahirnya konsep-konsep tentang pengakuan dan perlindungan terhadap hak-hak asasi manusia diarahkan kepada pembatasan-pembatasan dan peletakan kewajiban masyarakat dan pemerintah. ${ }^{6}$

Perlindungan hukum adalah adanya upaya melindungi kepentingan seseoang dengan cara mengalokasikan suatu kekuasaan kepadanya untuk bertindak dalam kepentinganya tersebut. Selanjutnya dikemukakan pula, salah satu sifat dan sekaligus merupakan tujuan dari hukum adalah memberikan perlindungan (pengayoman) kepada masyarakat. Oleh karena itu, perlindungan hukum terhadap masyarakat tersebut harus diwujudkan dalam bentuk adanya kepastian hukum. ${ }^{7}$

Pasal 86 ayat 1 Undang-undang Nomor 40 tahun 2007 berbunyi:

"RUPS dapat dilangsungkan jika dalam RUPS lebih dari 1/2 (satu perdua) bagian dari jumlah seluruh saham dengan hak suara hadir atau diwakili, kecuali Undangundang dan/atau anggaran dasar menentukan jumlah kuorum yang lebih besar".

Berdasarkan bunyi Pasal 86 ayat (1), dapat disimpulkan bahwa apabila kuorum belum mencapai lebih dari $50 \%$ dari jumlah saham sebagai hak suara yang hadir, maka RUPS tidak dapat dilangsungkan, akan tetapi pemegang saham mayoritas merasa jumlah sahamnya sudah mencukupi kuorum untuk dilangsungkannya RUPS, sehingga RUPS tetap dilangsungkan dengan mengabaikan kepentingan pemegang saham minoritas yang tidak hadir dalam RUPS. Jika pemegang saham mayoritas sudah hadir dan hak suaranya sudah mencukupi untuk dilangsungkan RUPS, maka RUPS tetap dilangsungkan oleh pemegang saham mayoritas tanpa kehadiran pemegang saham minoritas.

Salah satu alasan pemegang saham minoritas harus dilindungi antara lain karena sifat putusan oleh mayoritas dalam RUPS yang tidak selamanya fair bagi pemegang saham minoritas, meskipun cara pengambilan keputusan tersebut dianggap paling demokratis. Hal ini disebabkan dengan sistem putusan mayoritas tersebut, bisa saja seorang yang sudah membiayai perusahaan sebagai pemegang saham sampai dengan 48\% mempunyai kedudukan yang hampir sama dalam memberikan suara dengan pemegang saham yang hanya $1 \%$ saham dan akan sangat berbeda dengan pemegang saham 51\%. Hal ini akan menimbulkan ketidakadilan diantara pemegang saham. Oleh karena itu untuk menjaga agar terdapat keadilan bagi setiap pemegang saham, timbulah

\footnotetext{
${ }^{6}$ Hadjon, Philipus M. (1987).Perlindungan Hukum Bagi Rakyat Indonesia, Surabaya: Bina Ilmu, h.

7 Rahardjo, Satjipto. Op. Cit, h.
} 
prinsip yang disebut dengan "Kekuasaan Mayoritas dengan Perlindungan Minoritas" (Mayority Rule Minority Protection. ${ }^{8}$

\section{Penerapan prinsip-prinsip keadilan Pancasila dalam Perusahaan Terbatas tertutup oleh pemegang saham mayoritas terhadap pemegang saham minoritas}

Sebagaimana telah dikemukakan bahwa para pemegang saham minoritas tidak memiliki kendali atas perusahaan. Keuntungan langsung yang diterima oleh pemegang saham minoritas adalah deviden yang diterima dari perusahaan. Pemberian deviden inipun secara mutlak diputuskan oleh pemegang saham mayoritas dan hanya sebagian kecil dari keuntungan perseroan yang dibagi kepada pemegang saham minoritas. Bahkan pemegang saham minoritas hanya mempunyai informasi yang sangat terbatas mengenai apa yang sedang terjadi dalam perusahaan tersebut dibandingkan dengan yang dimiliki oleh pemegang saham mayoritas, dalam kondisi demikian, berarti telah terjdi pelanggaran hak pemegang saham minoritas. Dari hak untuk bersuara dalam RUPS sampai dengan hak untuk turut serta mengendalikan jalannya perseroan. Hal tersebut sangat merugikan pemegang saham minoritas. Kondisi demikian itu sehingga bagi pemegang saham minoritas memerlukan perlindungan hukum agar keadilan bagi pemegang saham minoritas dapat diwujudkan.

Prinsip-prinsip keadilan Pancasila di negara Indonesia dapat diterapkan untuk menyelesaikan permasalahan ini, prinsip utama keadilan Pancasila adalah musyawarah untuk mufakat sehingga apabila prinsip keadilan Pancasila ini diterapakan maka sebelum RUPS mengambil suatu keputusan harus dimusyawarahkan terlebih dahulu untuk mencapai mufakat.Untuk dapat bermusyawarah berarti harus ada para pihak, yaitu pemegang saham mayoritas dan pemegang saham minoritas, ini berarti pemegang saham mayoritas dan minoritas harus ada komunikasi yang baik untuk kemajuan perusahaan. Dari hal tersebut, dapat disimpulkan bahwa untuk dapat dilangsungkan RUPS berarti semua pihak harus hadir dalam RUPS dan bermusyawarah terlebih dahulu sebelum mengambil suatu keputusan. Apabila prinsip keadilan Pancasila tersebut diterapkan maka pemegang saham minoritas sebagai pihak yang dirugikan dan mendambakan keadilan tidak perlu menghubungkan secara langsung dengan hukum, misalnya mencari keadilan melalui jalur pengadilan dengan gugatan, sebab menurut keadilan Pancasila keadilan dan tata hukum merupakan substansi umum dari suatu masyarakat yang membuat dan menjaga kesatuannya.Pancasila merupakan cita hukum karena kedudukannya sebagai pokok kaedah fundamental negara (staatfundamental norm) yang mempunyai kekuatan sebagai grundnorm. Sebagai cita hukum, Pancasila menjadi bintang pemandu seluruh produk hukum nasional. Semua produk hukum ditujukan untuk mencapai ide-ide yang didukung Pancasila. ${ }^{9}$ Cita hukum dirumuskan dan dipahami untuk memudahkan penjabarannya kedalam berbagai perangkat aturan kewenangan dan aturan perilaku dan memudahkan terjaga konsistensi dalam penyelenggaraan hukum. ${ }^{10}$

Konsep keadilan menurut pandangan bangsa Indonesia tertuang dalam Pancasila yang merupakan filsafat bangsa. Di dalam literatur Indonesia, banyak pendapat yang mengatakan Pancasila sebagai filsafat, antara lain Notonagoro mengatakan Pancasila dalam negara Republik Indonesia sebagai dasar negara dalam pengertian filsafat. Konsep

\footnotetext{
8 Fuadi, Munir. (2001). Perseroan Terbatas Paradigma Baru, Bandung: Citra Aditya Bakti, h.

9 Notonagoro. Op. Cit, h.

10 Sidharta, B Arief. (2000), Refleksi Tentang Struktur Ilmu Hukum Sebuah Penelitian Tentang Fondasi Kefilsafatan dan Sifat Keilmuan Ilmu Hukum Sebagai Landasan Pengembangan Ilmu Hukum Nasional Indonesia, Bandung : Mandar Maju, h.
} 
keadilan dalam Pancasila dirumuskan dalam sila Kemanusiaan yang adil dan beradap. Sila kemanusiaan yang adil dan beradap pertama kali dijabarkan dalam Ketetapan MPR No. II/MPR/1978. Dalam rumusan tersebut, sikap adil digambarkan sebagai bermartabat, sederajat, saling mencintai, sikap tepaselira, tidak sewenang-wenang, mempunyai nilai kemanusiaan, membela kebenaran dan keadilan serta hormat menghormati dan kerjasama dengan bangsa lain. Makna adil dalam sila keadilan sosial bagi seluruh rakyat Indonesia adalah gotong-royong, keseimbangan antara hak dan kewajiban, memiliki fungsi sosial hak milik dan hidup sederhana. Jika mengacu pada rumusan tersebut maka konsep keadilan menurut pandangan bangsa Indonesia adalah keadilan sosial.

Sikap adil yang tertuang dalam Pancasila seharusnya diterapkan dalam menyelesaikan permasalahan berbagai permasalah yang muncul sehingga antara pemegang saham mayoritas dan pemegang saham minoritas dalam setiap dilangsungkan RUPS akan selalu bersikap dan memutuskan berbagai hal dengan menhasilkan putusan yang saling menguntungkan bagi kedua belah pihak, tidak hanya mengutamakan kepentingan masing-masing. Pemegang saham mayoritas tidak merasa selalu suaranya yang harus dijadikan sebagai suara hasil keputusan dalam RUPS, tetapi juga mempertimbangkan dan mendengarkan hak suara dari pemegang saham minoritas. Hal tersebut karena suara dari pemegang saham minoritas dapat pula memberikan kontribusi positif dan baik untuk kemajuan perseroan serta dapat menjadi masukan atau saran yang diperlukan untuk kemajuan perusahaan. Hal ini menunjukkan, kerjasama dan tepaselira antara pemegang saham mayoritas dan pemegang saham minoritas sangat dibutuhkan untuk kemajuan perusahaan. Apabila kemajuan perusahaan dapat dicapai itu berarti tujuaan dari didirikannya perusahaan sudah dapat diraih pula yaitu mendapatkan keuntungan yang sebesar-besarnya. Apabila konsep keadilan Pancasila diterapkan dalam setiap dilangsungkanRUPS demi kemajuan perusahaan, maka tingkat keberhasilan perusahaan tersebut akan meningkat pula. Demikian pula dengan sikap pemegang saham mayoritas, seyogyanya konsep Keadilan Pancasila diterapkan pula. Hal tersebut karena sikap adil yang terkandung dalam falsafah Pancasila digambarkan sebagai sikap yang bermartabat, sederajat, saling mencintai, sikap tepaselira, tidak sewenang-wenang, mempunyai nilai kemanusiaan, membela kebenaran dan keadilan serta hormat menghormati dan kerja sama. Maka demikian, sikap pemegang saham mayoritas terhadap pemegang saham minoritas dalam upaya untuk mewujudkan keadilan Pancasila seharusnya dapat memberikan jaminan bagi pemegang saham minoritas untuk mendapatkan keadilan sebagaimana keadilan yang dianut dalam Negara Hukum Pancasila. Demikian halnya, walaupun pemegang saham mayoritas dalam perseroan terbatas tertutup mempunyai kendali yang penuh atas perusahaan dan sebagai pihak yang mendominasi dalam pengambilan berbagai keputusan-keputusan penting bagi perusahaan, namun demikian demikian pemegang saham mayoritas, perlu memperhatikan dan mempertimbangkan pula pendapat dan masukan dari pemegang saham minoritas, sehingga berbagai keputusan penting selain menggambarkan sikap adil sebagaimana yang terkandung dalam falsafah Pancasila yaitu sikap yang bermartabat, sederajat, saling mencintai, sikap tepaselira, tidak sewenang-wenang, mempunyai nilai kemanusiaan, membela kebenaran dan keadilan serta hormat menghormati dan kerja sama, juga dapat menghasilkan kualitas keputusan yang lebih baik.

\section{PE N T U P}

Rapat Umum Pemegang Saham (RUPS) belum mencerminkan perlindungan hukum bagi pemegang saham minoritas. Hal tersebut dikarenakan dalam setiap pengambilan keputusan baik keputusan melalui RUPS maupun berbagai kebijakan 
perseroan lainnya selalu berdasar atas kuorum kehadiran dengan mengacu pada suara terbanyak yang hadir dalam Rapat Umum Pemegang Saham (RUPS). Hal demikian dapat merugikan kepentingan pemegang saham minoritas, karena tanpa kehadiran pemegang saham minoritas, RUPS tetap dilangsungkan sedangkan pemegang saham minoritas mempunyai hak dan kewajiban serta tanggung jawab yang sama terhadap Perseroan.

Prinsip-prinsip keadilan Pancasila belum sepenuhnya dilaksanakan dalam perseroan terbatas tertutup, sedangkan hal tersebut seharusnya diterapkan untuk menyelesaikan berbagai masalah dalam perseroan terbatas tertutup, karena prinsip utama keadilan Pancasila berdasar pada musyawarah untuk mufakat. Jika prinsip keadilan Pancasila tersebut diterapkan dalam perseroan terbatas tertutup, maka sebelum RUPS mengambil suatu keputusan harus dimusyawarahkan terlebih dahulu untuk mencapai mufakat. Jika prinsip keadilan Pancasila tersebut diterapkan maka pemegang saham minoritas memperoleh keadilan menurut keadilan Pancasila, yaitu adanya sikap adil yang bermartabat, sederajat, saling mencintai, sikap tepaselira, tidak sewenang-wenang, mempunyai nilai kemanusiaan, membela kebenaran dan keadilan serta hormat menghormati dan kerjasama dengan bangsa lain.

\section{DAFTAR PUSTAKA}

\section{Buku}

[1] Fuadi, Munir. (2001), Perseroan Terbatas Paradigma Baru, Bandung: Citra Aditya Bakti.

[2] Hadjon, Philipus M. (1987).Perlindungan Hukum Bagi Rakyat Indonesia, Surabaya: Bina Ilmu.

[3] Kuswiratmo, Bonifasius Aji. (2016). Keuntungan dan Resiko Menjadi Direktur, Komisaris dan Pemegang Saham, Jakarta: Visimedia Pustaka.

[4] Notonagoro. (1974). Pancasila Dasar Falsafah Negara, Jakarta: Pancuran Tujuh.

[5] Rahardjo, Satjipto. (1983). Permasalahan Hukum di Indonesia, Bandung: Alumni.

[6] Sidharta. B. Arief. (2000). Refleksi Tentang Struktur Ilmu Hukum Sebuah Penelitian Tentang Fondasi Kefilsafatan dan Sifat Keilmuan Ilmu Hukum Sebagai Landasan Pengembangan Ilmu Hukum Nasional Indonesia, Bandung : Mandar Maju.

\section{Jurnal dan Lain-Lain}

[7] Sjahdeini, Sutan Remy. (2005). Pengantar dalam buku Misahardi Wilamarta, Hak Pemegang Saham Minoritas Dalam Rangka Good Corporate Governance, Jakarta: Program Pasca Sarjana Fakultas Hukum Universitas Indonesia.

[8] Wilamarta, Misahardi. (2005).Hak Pemegang Saham Minoritas Dalam Rangka Good Corporate Governance, Jakarta: Program Pasca Sarjana Fakultas Hukum Universitas Indonesia. 